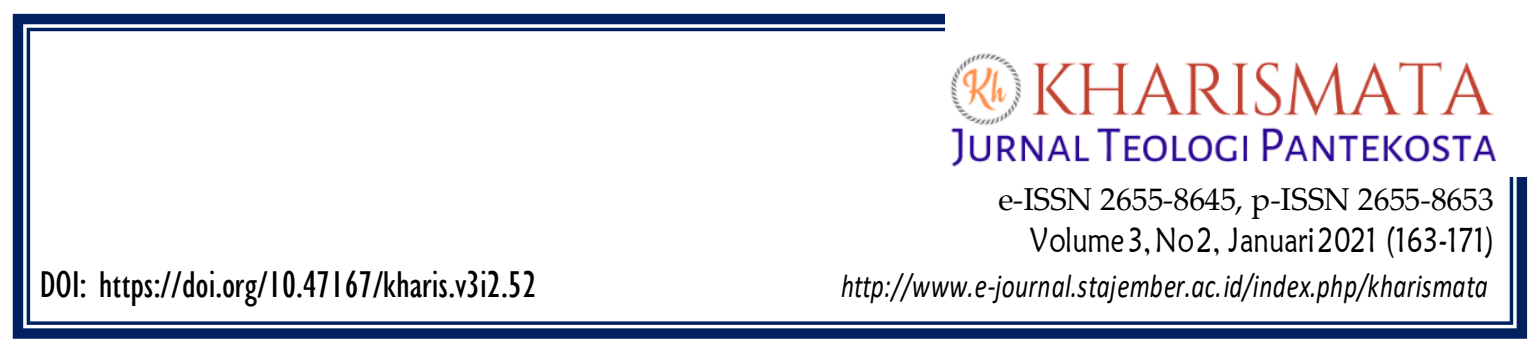

\title{
Mengaplikasikan Kisah Para Rasul 2-6 bagi Pertumbuhan Gereja di GPdI Elohim Sentani, Papua
}

\author{
Simson Sonny Manoach ${ }^{1}$, Sutikto ${ }^{2}$ \\ 1,2Pascasarjana Sekolah Tinggi Alkitab Jember, Jawa Timur \\ 1simsonmanoach@gmail.com,2liem.sutikto57@gmail.com
}

\begin{abstract}
God wishes the growth of the church as an implementation of the great commission of Jesus Christ. However, many churches are still not doing their best, so they are stagnating. Growth is meant not just a quantitative increase, but rather spiritual growth, number and management and outward expansion. A relevant strategy is needed in order to experience growth. This article aims to apply the growth strategy that the early church experienced, according to the text of Acts 2-6. This research was conducted using library research methods and field research methods. Build the theoretical basis of the exposition of the Book of Acts regarding the strategy of church growth. In addition, structured interviews were used, and through administrative documents, observations of congregants involved in local church services at GPdI Elohim, Sentani, Jayapura.
\end{abstract}

Key words: Acts of the Apostles; church growth; GPdI Elohim

Abstrak. Allah menghendaki pertumbuhan gereja sebagai implementasi dari amanat agung Yesus Kristus. Namun banyak gereja masih belum melakukannya secara maksimal, sehingga mengalami stagnasi. Pertumbuhan yang dimaksud bukan sekadar pertambahan kuantitatif, namun lebih kepada pertumbuhan rohani, jumlah dan menajemen dan ekspansi keluar. Diperlukan strategi yang relevan agar dapat mengalami pertumbuhan. Artikel ini bertujuan untuk menerapkan strategi pertumbuhan yang dialami gereja mula-mula, sesuai teks Kisah Para Rasul 2-6. Penelitian ini dilakukan dengan metode metode penelitian kepustakaan (library research) dan lapangan (field research). Membangun landasan teori dari eksposisi Kitab Kisah Para Rasul berkenaan dengan strategi pertumbuhan gereja. Selain itu, digunakan juga wawancara terstruktur, dan melalui dokumen administrasi, observasi terhadap jemaat yang terlibat dalam pelayanan gereja lokal di GPdI Elohim, Sentani, Jayapura.

Kata kunci: GPdI Elohim; Kisah Para Rasul; pertumbuhan gereja

\section{PENDAHULUAN}

Pertumbuhan gereja adalah kehendak Allah Tri Tunggal yang diwujudkan melalui Tuhan Yesus Kristus sebagai kepala Gereja. Selain menjadi impian banyak pemimpin gereja, pertumbuhan gereja juga menjadi salah satu yang Allah kehendaki dari umat Tuhan, baik itu secara kualitatif maupun kuantitatif. Pertumbuhan gereja dapat distimulasi oleh banyak faktor, seperti model ibadah atau liturgi, manajemen gereja, pelaksanaan komsel dan pemuridan, hingga pada hal yang paling klasik dan berkarakteristik, yakni penginjilan, yang selama ini dianggap sebagai implementasi dari 
amanat Agung Yesus Kristus. ${ }^{1}$ Pertumbuhan gereja yang dimaksud tentu mencakup pertumbuhan dalam aspek, kuantitas dan kualitas iman orang percaya, yang diimplementasikan dalam tindakan nyata, hidup dalam persekutuan dengan Tuhan dan sesama orang percaya. Namun, tidak hanya dalam suatu kelompok orang percaya saja, melainkan juga bersosialisasi dengan masyarakat di dalam semua konteks di mana gereja berada. ${ }^{2}$

Pertumbuhan Gereja dimulai dari pertumbuhan kualitas karena pekerjaan Roh Kudus memenuhi para murid Yesus, disusul dengan pertumbuhan secara kuantitas. Dalam Kisah Para Rasul 2-6 pola pertumbuhan tersebut terlihat dengan gamblang. Jika memperhatikan dalam kitab Kisah Para Rasul, terlihat dimensi kuantitas dari pertumbuhan gereja mula-mula secara jelas. Gereja mula-mula yang awalnya terdiri 120 orang saja (Kis. 1:15), namun setelah itu kelompok ini bertambah jumlahnya menjadi 3000 orang (Kis. 2:41). Di akhir bagian pasal 2 tersebut dijelaskan oleh penulis kitab Kisah Para Rasul bahwa tiap-tiap hari Tuhan menambah jumlah mereka (Kis. 2:47), sehingga menjadi 5000 orang (Kis. 4:4). Bahkan, jumlah terebut masih terus meningkat di mana dituliskan peningkatan itu dengan beberapa istilah: "banyak orang, semua orang, hampir seluruh kota, banyak murid, bertambah besar jumlahnya" (Kis. 13:43-44, 48; 14:21; 16:5; 17:4, 12). ${ }^{3}$

Gereja Pentakosta di Indonesia "Elohim" Sentani Papua mempunyai keunikan tersendiri. Bila dilihat dari statistiknya pertumbuhan Gereja ini sangat lambat, tidak sesubur pertumbuhan gereja pada abad permulaan. Sejak berdirinya tahun 1994, hingga tahun 2004, anggota jemaat berjumlah 87 jiwa, yang berarti rata-rata pertumbuhan 8,7 jiwa per tahun. Lalu, pertumbuhan 2004-2014 menjadi 205 jiwa, yang berarti rata-rata pertumbuhannya 11,8 jiwa per tahun; pada 2014-2018 menjadi 250 jiwa. Dengan demikian pertumbuhan secara kuantitasnya rata-rata 11,25 jiwa per tahun. Selama 24 tahun rata-rata pertumbuhannya 10,41 jiwa per tahun, atau pertumbuhan 0,87 jiwa per bulan.

Dengan memperhatikan statistik tersebut di atas, sangat jelas bahwa pertumbuhan jemaat di GPdI Elohim, Sentani, Papua kurang menunjukkan angka yang dinamis. Selama 24 tahun GPdI Elohim Sentani Papua berdiri, pertumbuhannya tidak mengalami signifikansi jika dibandingkan model yang ada dalam Kisah Para Rasul.

\footnotetext{
${ }^{1}$ Handreas Hartono, "Mengaktualisasikan Amanat Agung Matius 28 : 19-20 Dalam Konteks Era Digital," KURIOS (Jurnal Teologi dan Pendidikan Agama Kristen) 4, no. 2 (2018): 19-20, www.sttpb.ac.id/e-journal/index.php/kurios; Susanto Dwiraharjo, "Kajian Eksegetikal Amanat Agung Menurut Matius 28 : 18-20," Jurnal Teologi Gracia Deo 1, no. 2 (2019): 56-73, http://sttbaptisjkt.ac.id/e-journal/index.php/graciadeo; Y M Imanuel Sukardi, “Gereja Ekstra Biblikal Dan Tanggung Jawab Dalam Menyelesaikan Amanat Agung," KHARISMATA: Jurnal Teologi Pantekosta 1, no. 2 (2019): 37-39, http://www.e-journal.stajember.ac.id/index.php/kharismata/article/view/22. Fransiskus Irwan Widjaja, Daniel Ginting, and Sabar Manahan Hutagalung, "Teologi Misi Sebagai Teologi Amanat Agung," THRONOS: Jurnal Teologi Kristen 1, no. 1 (2019): 17-24.

2 Makmur Halim, Gereja di Tengah Perubahan Dunia, (Malang: Gandum Mas, 2000), 15

${ }^{3}$ Amelia Luise Doeka, Studi Aplikatif Delapan Prinsip Pertumbuhan Gereja Alamiah Ke Dalam Pertumbuhan Gereja GKII Talitakumi Makassar. (Makassar: Tesis Sekolah Tinggi Theologia Jaffray, 2005), 11
} 
Adapun penyebabnya diduga karena beberapa faktor, baik eksternal maupun internal. Secara eksternal ada pengaruh adat-istiadat dan budaya masyarakat yang hidup bertentangan dengan Injil, di mana nasihat-nasihat kepala suku dianggap sebagai sebuah kebenaran, sehingga masyarakat cenderung lebih menghormati kepala suku dan menerima nasihatnya dari pada pendeta. Selain masih rendahnya pengetahuan, dan cenderung dibutakan oleh ilah zaman. Faktor internalnya adalah: Belum semua jemaat yang dapat menjadi teladan hidup dalam terang di tengah masyarakat, belum adanya perencanaan pelaksanaan amanat agung yang baik, belum maksimalnya persekutuan hidup yang saling melayani dalam kasih di kalangan jemaat gereja lokal, belum maksimalnya penerapan pelayanan diakonia di dalam gereja lokal, dan belum maksimalnya kepemimpinan di kalangan jemaat.

Dari beberapa persoalan yang dihadapi dalam rangka memacu pertumbuhan gereja di GPdI Sentani, Jayapura, faktor strategi penginjilan menjadi hal yang perlu dikembangkan. Artikel ini bertujuan untuk mengetahui strategi pertumbuhan gereja yang ada dalam Kisah Para Rasul 2-6, sehingga dapat diterapkan sebagai strategi pertumbuhan gereja di GPdI Sentani Jayapura. Ada beberapa kajian mengenai Kisah Para Rasul, seperti yang dilakukan oleh Harls Evan Siahaan, baik dalam bentuk pemahaman yang prasuposisi ${ }^{4}$, atau tentang karakteristik Pentakostalisme. ${ }^{5}$ Selain itu, ada kajian dari Sonny Eli Zaluchu yang membahas gereja atau jemaat mula-mula ${ }^{6}$, dan Yushak Soesilo yang menekankan perilaku sosial jemaat mula-mula7; semua yang dilakukan masih terkait dengan eksistensi jemaat mula-mula, belum memberikan kajian mengenai pertumbuhannya. Memang Adi Putra telah melakukan kajian pertumbuhan gereja pada teks Kisah Para Rasul 2:41-478, namun kajian itu masih belum memperlihatkan perkembangan yang lebih luas seperti yang dilakukan dalam penelitian ini, karena mencakup hingga Kisah Para Rasul 6. Dan inilah yang menjadi gap dalam kajian ini, yang memperlihatkan pertumbuhan terkait penerapan strategi penginjilan.

\section{METODE PENELITIAN}

Berdasarkan paradigma penelitian, maka penelitian ini hendak mengemukakan asumsi penelitian yaitu tentang pemahaman dan pengalaman informan mengenai strategi pertumbuhan gereja dalam Kitab Kisah Para Rasul. Pada 6 dimensi atau sub-

\footnotetext{
${ }^{4}$ Harls Evan R. Siahaan, "Presuposisi Kitab Kisah Para Rasul Dalam Rancang Bangun Teologi Pentakosta," KURIOS (Jurnal Teologi dan Pendidikan Agama Kristen) 4, no. 1 (April 11, 2020): 56-73, accessed April 20, 2018, http://www.sttpb.ac.id/e-journal/index.php/kurios/article/view/34/48.

${ }^{5}$ Harls Evan Siahaan, “Karakteristik Pentakostalisme Menurut Kisah Para Rasul," Dunamis: Jurnal Teologi dan Pendidikan Kristiani 2, no. 1 (2017): 12-28.

${ }^{6}$ Sonny Eli Zaluchu, "Eksegesis Kisah Para Rasul 2:42-47 Untuk Merumuskan Ciri Kehidupan Rohani Jemaat Mula-Mula Di Yerusalem," EPIGRAPHE: Jurnal Teologi dan Pelayanan Kristiani 2, no. 2 (2018): 72-82, accessed April 1, 2020, http://www.stttorsina.ac.id/jurnal/index.php/epigraphe.

${ }^{7}$ Yushak Soesilo, "Pentakostalisme Dan Aksi Sosial: Analisis Struktural Kisah Para Rasul 2:4147," DUNAMIS: Jurnal Teologi dan Pendidikan Kristiani (2018).

${ }^{8}$ Adi Putra, "Hakikat Pertumbuhan Gereja Berdasarkan Kisah Para Rasul 2: 41-47," BIA': Jurnal Teologi dan Pendidikan Kristen Kontekstual 3, no. 2 (2020): 262-281.
} 
fokus penelitian ini digali dari dalam Kitab Kisah Para Rasul, dan kemudian menjadi landasan teori dalam upaya peningkatan kualitas pelayanan jemaat dalam konteks pertumbuhan gereja. Untuk mencapai tujuan penelitian, maka metode yang digunakan adalah metode penelitian kepustakaan atau literatur (library research), serta penelitian lapangan (field research) yang bersifat partisipatif. Selain itu ada metode analisi teks Kisah Para Rasul. Itu sebabnya, dalam membangun landasan teori diperlukan eksposisi Kitab Kisah Para Rasul yang berkenaan dengan strategi pertumbuhan gereja. Selain itu menggunakan beberapa sumber literatur yang memuat pendapat pakar teologi praktika tentang pertumbuhan Gereja.

Juga akan diperoleh data dari lapangan melalui wawancara terstruktur, dan melalui dokumen administrasi, observasi kepada jemaat yang terlibat dalam pelayanan gereja lokal di GPdI Elohim Sentani, Jayapura. Pendekatan penelitian ini adalah pendekatan kualitatif. Dasar teorinya khusus mengunakan penelitian penafsiran Alkitab. Berkaitan hal tersebut, Andreas Subagio mengatakan bahwa penafsiran Alkitab adalah suatu penelitian biblika yang bertujuan mengeluarkan makna teks. ${ }^{9}$ Karena penelitian ini hendak mengetahui pemahaman dan pendapat, dan pengalaman informan tentang strategi pertumbuhan gereja berdasarkan Kisah Para Rasul, maka jenis penelitian ini adalah studi fenomenologi yang teologis, dengan landasan kebenarannya dari teks Alkitab. Penelitian ini berupaya membangun pemahaman yang riil, yang dibangun dari sudut pandang informan tentang apa yang mereka pahami, pikirkan, katakan, dan lakukan sendiri.

\section{HASIL DAN PEMBAHASAN}

\section{Strategi Pertumbuhan Gereja}

Strategi adalah pendekatan secara keseluruhan yang berkaitan dengan pelaksanaan gagasan, perencanaan, dan eksekusi sebuah aktivitas dalam kurun waktu tertentu, "Strategi merupakan taktik untuk memenangkan satu pertandingan atau untuk meraih keberhasilan. ${ }^{10}$ Pertumbuhan gereja berkaitan dengan kata misi, artinya perutusan untuk melakukan tugas penting. Istilah misi (mission) berasal dari bahasa Latin "missio" yang diangkat dari kata dasar "mittre," yang berkaitan dengan kata "missum," yang artinya (mengirim/mengutus). Padanan dari kata ini dalam bahasa Yunani ialah "apostello." Kata" apostello'ini tidak berarti mengirim atau kirim (pempo) secara umum. Istilah ini lebih berarti mengutus dengan otoritas. Di sini, yang dikirim diutus dengan otoritas dari Yang mengirim, untuk tujuan khusus yang akan dicapai. Tekanan penting dari "misi atau pengutusan Allah" sebagai Pengutus dimana Ia adalah sumber; inisiator, dinamisator, pelaksana, dan penggenap misi-Nya. Sebagai sumber misi, landasan bagi rencana Allah yang kekal ini beranjak dari hati-

${ }_{9}^{9}$ Andreas Bambang Subagio, Pengantar Riset Kualitatif \& Kuantitatif, (Bandung: Kalam Hidup, 2004), 140-145

${ }^{10}$ Halim Wiryadinata, "Mission And Evangelism : African Context," KURIOS (Jurnal Teologi dan Pendidikan Agama Kristen) 3, no. 1 (2015): 1-11, http://www.sttpb.ac.id/e-journal/index.php/kurios. 
Nya dan Dia sendiri yang berinisiatif untuk melaksanakan misi-Nya, ditunjang oleh dinamika-Nya (kekuatan dan kuasa) guna dapat melaksanakan dan mencapai target misi-Nya tersebut.

Strategi pertumbuhan gereja atau taktik untuk pelipatgandaan bagi kelangsungan gereja memenuhi bumi bagi kemuliaan Allah. Melalui pelayanan koinonia atau persekutuan dengan Tuhan, melalui didaskalia atau pengajaran, melalui persekutuan dengan sesama atau diakonia, melaui doa, bersaksi, penetapan pemimpin, dan kepemimpinan. Jika gereja sehat, maka secara alamiah gereja pasti bertumbuh. ${ }^{11}$

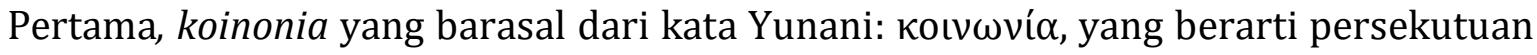
dengan partisipasi intim (Kis 2:42). Pelayanan koinonia dengan adanya persekutuan yang kuat di dalam Yesus Kristus Sang Kepala Gereja. Adanya pemberitaan Injil Kerajaan Allah, adanya pembaptisan orang percaya, perjamuan kudus dan pujian dan penyembahan.

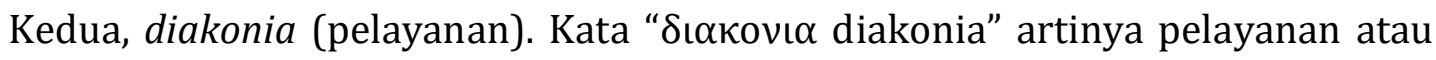
bantuan (Kis 6:1). Pertumbuhan gereja melalui pelayanan diakonia, saling berbagi satu dengan yang lainnya, sehati, sejiwa, satu tujuan bagi kemuliaan Allah. Kerelaan berkorban bagi pemenuhan kebutuhan jasmani jemaat yang berkekurangan, adanya sukacita dan ketulusan dalam memberi diantara orang beriman, adanya pelayanan kasih dengan makan bersama. George Eldon Ladd mengatakan, "Persekutuan adalah orang yang terpilih tanpa melihat status sosial, pendidikan, kekayaan atau warna kulit dengan sederhana disebut orang pilihan Allah, gereja adalah persekutuan orang kudus atau orang yang disucikan yang lazim digunakan oleh Paulus untuk menjelaskan orang-orang Kristen."12

Ketiga, marturia (bersaksi), dalam Kisah Para Rasul 2:40. Marturia (dari bahasa Yunani: martyria) adalah salah satu istilah yang dipakai gereja dalam melakukan aktivitas imannya ${ }^{13}$, sebagai tugas panggilan gereja, yaitu dalam hal kesaksian iman. Kesaksian iman yang dimaksud adalah pemberitaan Injil sebagai berita keselamatan bagi manusia. Marturia biasanya disandingkan dengan tugas gereja yang lain, yaitu koinonia yang berarti persekutuan dan diakonia atau pelayanan. Kata "marturia" sendiri sangat dekat dengan kata "martir" (dalam bahasa Arab: "syahid"), yaitu orangorang yang mati karena memberitakan Injil pada zaman sesudah Yesus Kristus. Memang banyak orang Kristen perdana yang harus mengalami penganiayaan karena kepercayaannya, dan pengorbanan ini terus berlanjut sampai sekarang. Karenanya, istilah "marturia" dan "martir" itu banyak kali dirancukan, dan diasosiasikan dengan para "syuhada", yaitu orang-orang Kristen yang disiksa sampai mati karena imannya,

\footnotetext{
11 Amelia Luise Doeka, Studi Aplikatif, 8. 335.

12 George Eldon Ladd, Teologi Perjanjian Baru Jilid II (Bandung: Yayasan Kalam Hidup, 1999),

13 Arniman Zebua, "Iman Yang Bertumbuh Melalui Keteladanan Hamba Tuhan”, IMMANUEL: Jurnal Teologi dan Pendidikan Kristen 1, No.1, (2020): 43-51, http://stt-su.ac.id/ejournal/index.php/immanuel/article/view/6
} 
atau para misionaris yang dibunuh dalam menjalankan tugasnya, menyampaikan berita Injil ke tempat-tempat yang belum pernah mendengar berita itu. ${ }^{14}$ Istilah "evangelisme" ini tidak terkait dengan tradisi Kristen mana pun, dan tidak sama dengan istilah Evangelikalisme, suatu kata yang dipakai untuk menyebut kelompok atau gereja "Protestan Evangelikal" atau "Injili". Strategi Pertumbuhan Gereja melalui bersaksi, yaitu bersaksi dengan menyatakan kuasa Allah, bersaksi tentang kasih yang berpusat pada Yesus Kristus, bersaksi tentang karya Yesus di salib, bersaksi dengan penuh keberanian, bersaksi yang berdampak bagi kemuliaan Allah, bersaksi di kumpulan orang banyak, dan bersaksi dengan membungkam saksi palsu, serta tetap bersaksi walaupun disertai berbagai penderitaan. Sularso Sopater berkomentar tentang jenis pertumbuhan ini dengan "bertambahnya jumlah anggota, kelompok, luas jangkauan pelayanan, organisasi dan sebagainya ${ }^{15}$.

Pertumbuhan Gereja adalah kehendak Allah, dan Allahlah sumber pertumbuhan Gereja. Kitab Kisah Para Rasul pasal 2-6 dalam penelitian ini menunjukkan sejarah lahir dan bertumbuhnya gereja di dunia berdasarkan pelaksanaan amanat Agung dengan isi berita salib dan kebangkitan Yesus Kristus. Petumbuhan gereja mula-mula melalui penginjilan dari Yerusalem sampai keujung bumi, adanya persekutuan hidup antara orang percaya dengan Tuhan, persekutuan diantara sesama orang percaya dengan pelayanan sosial dan adanya manajemen yang baik.

\section{Interpretasi Data Penelitian}

Mayoritas partisipan cukup memahami tentang strategi pertumbuhan gereja bedasarkan Kisah Para Rasul bahwa: Pertama, Pertumbuhan melalui pelaksanaan amanat Agung Yesus Kristus: Fokus pada visi, misi, tujuan Allah, Misi pekerjaan Roh Kudus (berbagai karunia dan buah). ${ }^{16}$ Isi berita Injil (salib dan kebangkitan) adalah kepastian keselamatan; iman, pertobatan, baptisan, dan terima Roh Kudus. Pemberitaan Injil secara meluas; berapologia menghadapi tuduhan palsu; sukacita dalam aniaya sebagai murid Kristus; pelepasan dari penderitaan ${ }^{17}$. Kedua, hidup dalam persekutuan (koinonia): sehati; bertekun dalam pengajaran; berintegritas/wibawa; memuji Allah. Ketiga, melaksanakan pelayanan (diakonia); rela berkorban; berkumpul makan bersama. Keempat, melaksanakan manajemen konflik; organisasi yang sehat (manajemen); memilih diaken; kualifikasi diaken baik, penuh Roh, penuh iman, berhikmat; penumpangan tangan; doa.

\section{Aplikasi Strategi Pertumbuhan Gereja di GPdI Elohim Sentani - Papua}

Kitab Kisah Para Rasul memperlihatkan bahwa adanya strategi pertumbuhan

14 Andreas A. Yewangoe., Tidak Ada Penumpang Gelap, (Jakarta: BPK Gunung Mulia, 2009)

15 Sularso Sopater, "Pertumbuhan Gereja Secara Alkitabiah dan Teologi" dalam Buku Makalah Seminar Pertumbuhan Gereja, (Jakarta: Panitia SPG, 1989), 31.

${ }^{16}$ Harls Evan R Siahaan, "Aktualisasi Pelayanan Karunia Di Era Digital," EPIGRAPHE: Jurnal Teologi dan Pelayanan Kristiani 1, no. 1 (2018): 23-38.

17 Yanti Imariani Gea, "Iman Orang Percaya dalam Menghadapi Tantangan dan Pergumulan Hidup”, IMMANUEL: Jurnal Teologi dan Pendidikan Kristen 1, No.1, (2020): 25-32, http://sttsu.ac.id/e-journal/index.php/immanuel/article/view/4 
Gereja yang dapat diaplikasikan bagi gereja segala zaman. Dengan demikian, masih relevan strategi pertumbuhan Gereja dalam Kisah Para Rasul diterapkan dalam pelayanan GPdI Elohim, Papua. Aplikasi strategi tersebut antara lain:

Pertama, koinonia (persekutuan). Jemaat harus memiliki persekutuan yang kuat di dalam nama Yesus (Kis. 2:1), adanya: kehadiran ilahi (Kis. 2:2-3); kepenuhan Roh Kudus (Kis. 2:4-5); adanya bukti manifestasi Roh Kkudus (Kis. 2:2-13). Kedua, anggota jemaat harus melaksanakan pemberitaan injil Kerajaan Allah (Kis. 2:14-37): menyatakan penggenapan nubuatan Firman Allah (Kis. 2:17-20); menyatakan rahasia keselamatan dalam Tuhan Yesus (Kis. 2:21-28); menyatakan keutamaan Kristus dari Daud (Kis. 2:29-36); menjamah dan mengubah hati pendengar (Kis. 2:37). Ketiga, anggota jemaat harus menghasilkan buah penginjilan hingga terjadi pembaptisan bagi orang percaya (Kis. 2:38,41): membaptis orang yang bertobat; adanya penyerahan diri kepada Tuhan; orang percaya menerima pengampunan; orang percaya menerima karunia Roh Kudus dan janji Allah; serta, meningkatkan pertumbuhan dan pertambahan jemaat.

Keempat, anggot jemaat adalah orang percaya yang dipersatukan secara rohani dalam sakramen Perjamuan Kudus (Kis. 2:46); mereka hidup dalam pujian dan penyembahan (Kis. 2:47). Kelima, anggota jemaat bertumbuh dalam didache (pengajaran, Kis. 2:42a); adanya pengajaran yang sehat; pembelajar yang tekun, disertai materi ajar yang alkitabiah tentang Kristus, keselamatan, Roh Kudus, gereja, misi penginjilan, dan pelayanan sosial. Keenam, Jemaat melaksanakan diakonia (pelayanan, Kis. 2:44-46); diakonia dalam kesatuan (hati, jiwa, dan tujuan, Kis. 2:44a); diakonia dalam kepemilikan bersama (Kis. 2:44b); diakonia lewat hasil penjualan (Kis. 2:45); diakonia untuk menjawab kebutuhan masing-masing jemaat (Kis.2:45); diakonia dalam sukacita dan ketulusan (Kis. 2:46); diakonia dalam perjamuan kasih (Kis.2:46), diakonia yang menambah orang yang diselamatkan tiap-tiap hari ( Kis. 2:47).

Ketujuh, Jemaat harus menjadi orang yang berdoa (Kis. 2:42; 4:31; 6:4; 6:6), sebab doa penopang pelayanan diakonia (Kis. 2:42); doa penopang pelayanan marturia (Kis. 4:31); doa yang menyatakan kuasa Allah; doa yang mengakibatkan kepenuhan Roh Kudus; doa yang mengakibatkan keberanian untuk memberitakan injil kerajaan Allah; doa penopang pelayanan firman Allah; doa dengan memusatkan pikiran kepada Allah; doa yang mendatangkan roh hikmat dan wahyu; doa penumpangan tangan, pengukuhan para pelayan sebelum memulai pekerjaan pelayanan, pelepaskan wewenang dan otoritas untuk melayani. Kedelapan, jemaat melaksanakan marturia (bersaksi, Kis. 2:40), aktifitas bersaksi dengan menyatakan kuasa ilahi (Kis. 3:1-10; 4:33; 5:12-16); bersaksi dengan kesaksian yang berpusat kepada Kristus (Kis. 3:13-20); bersaksi tentang karya keselamatan Yesus Kristus (Kis. 4:11-12, 33); bersaksi dengan penuh keberanian (Kis. 4:13, 19; 4:29; 5:29); bersaksi yang berdampak pada kemuliaan Allah (Kis. 4:21); bersaksi dan menjadi saksi (Kis. 5:1-4); bersaksi di kumpulan orang banyak (Kis. 5:20,32); bersaksi membungkam para saksi 
palsu (Kis. 5:36); bersaksi walau didera derita (Kis. 5:40-41).

Kesembilan, Jemaat harus menetapkan pemimpin dan kepemimpinan gereja (Kis. 6:1-7). Adanya pemimpin yang peka terhadap masalah (Kis. 6:1-2); pemimpin yang menyadari keterbatasannya (Kis. 6:3,5); pemimpin yang mempunyai kriteria rohani, terkenal baik, penuh Roh Kudus, penuh hikmat dan penuh iman; pemimpin yang setia sampai titik darah terakhir. Kesepuluh, Jemaat harus memiliki kepemimpinan (Kis. 6:4; 5, 7). ${ }^{18}$ Pembagian dan pendelegasian tugas pelayanan, fokus pada pelayanan sesuai karunia/kapasitas rohani para pelayan, menjawab tantangan pelaya-nan dengan cara musyawarah dan mufakat, menjangkau para pemimpin di luar komunitas orang percaya.

\section{KESIMPULAN}

Berdasarkan penelitian yang sudah dilakukan, maka dapat disimpulkan bahwa pertumbuhan Gereja dalam Kisah Para Rasul 2-6 didukung oleh adanya berbagai hal yang dikategorikan sebagai sebuah strategi, yaitu: koinonia (persekutuan), Pemberitaan Injil Kerajaan Allah (Kis.2:14-37), didakhe (pengajaran), diakonia (pelayanan). Pertumbuhan Gereja dalam Kisah Rasul disertai adanya doa yang menopang pelayanan diakonia (Kis. 2:42), pelayanan marturia (bersaksi, Kis. 2-6), penetapan pemimpin dan kepemimpinan Gereja (Kis. 6:1-7). Penelitian ini memberikan kontribusi bagi strategi pertumbuhan gereja yang dapat diaplikasikan di GPdI Elohim Sentani, Jayapura, berdasarkan kajian Kisah Para Rasul 2-6. Jemaat GPdI Elohim Sentani, Papua dapat mengikuti strategi pertumbuhan gereja dalam Kitab Kisah Para Rasul 26 sebagai berikut: memulai dengan pekerjaan Roh Kudus (Kis. 1-2); melaksanakan amanat agung (Mat. 28:17-20; Kis. 2-6); melaksanakan pelayanan koinonia (Kis. 2:4147), melaksanakan pelayanan diakonia (Kis. 6:1-15); melaksanakan kepemimpinan dengan baik (Kis. 6:6-6). Kajian ini merekomendasikan penelitian berikutnya dalam bentuk penerapan masing-masing aspek atau unsur yang disebutkan di atas.

\section{REFERENSI}

Doeka, Amelia Luise, Studi Aplikatif Delapan Prinsip Pertumbuhan Gereja Alamiah Ke Dalam Pertumbuhan Gereja GKII Talitakumi Makassar. Makassar: Tesis Sekolah Tinggi Theologia Jaffray, 2005

Gea, Yanti Imariani, "Iman Orang Percaya dalam Menghadapi Tantangan dan

Pergumulan Hidup", IMMANUEL: Jurnal Teologi dan Pendidikan Kristen 1, No.1, (2020): 25-32, http://stt-su.ac.id/ejournal/index.php/immanuel/article/view/4

Dwiraharjo, Susanto. "Kajian Eksegetikal Amanat Agung Menurut Matius 28 : 18-20." Jurnal Teologi Gracia Deo 1, no. 2 (2019): 56-73. http://sttbaptisjkt.ac.id/ejournal/index.php/graciadeo.

18 Irwanto Sudibyo, "Pelayanan Kepemimpinan Penggembalaan Menurut Kisah Para Rasul 20:17-38," Jurnal Teologi Gracia Deo 2, no. 1 (2019): 46-61. 
Hartono, Handreas. "Mengaktualisasikan Amanat Agung Matius 28 : 19-20 Dalam Konteks Era Digital." KURIOS (Jurnal Teologi dan Pendidikan Agama Kristen) 4, no. 2 (2018): 19-20. www.sttpb.ac.id/e-journal/index.php/kurios.

Halim, Makmur, Gereja di Tengah Perubahan Dunia, (Malang: Gandum Mas, 2000

Kristanto, K. (2019, June 30). Dasar Alkitabiah dan Teologis Pertumbuhan Gereja. KINAA: Jurnal Teologi, 4(1).https://doi.org/https://doi.org/10.0302/kinaa.v4i1.1059, http://journals.ukitoraja.ac.id/index.php/kinaa/article/view/1059

Ladd, George Eldon, Teologi Perjanjian Baru Jilid II (Bandung: Yayasan Kalam Hidup, 1999.

Putra, Adi. "Hakikat Pertumbuhan Gereja Berdasarkan Kisah Para Rasul 2: 41-47."

BIA': Jurnal Teologi dan Pendidikan Kristen Kontekstual 3, no. 2 (2020): 262-281.

Siahaan, Harls Evan. "Karakteristik Pentakostalisme Menurut Kisah Para Rasul." Dunamis: Jurnal Teologi dan Pendidikan Kristiani 2, no. 1 (2017): 12-28.

Siahaan, Harls Evan R. "Presuposisi Kitab Kisah Para Rasul Dalam Rancang Bangun Teologi Pentakosta." KURIOS (Jurnal Teologi dan Pendidikan Agama Kristen) 4, no. 1 (April 11, 2020): 56-73. Accessed April 20, 2018. http://www.sttpb.ac.id/e-journal/index.php/kurios/article/view/34/48.

Siahaan, Harls Evan R. "Aktualisasi Pelayanan Karunia Di Era Digital." EPIGRAPHE: Jurnal Teologi dan Pelayanan Kristiani 1, no. 1 (2018): 23-38.

Soesilo, Yushak. "Pentakostalisme Dan Aksi Sosial: Analisis Struktural Kisah Para Rasul 2:41-47.” DUNAMIS: Jurnal Teologi dan Pendidikan Kristiani (2018).

Sopater, Sularso, "Pertumbuhan Gereja Secara Alkitabiah dan Teologi" dalam Buku Makalah Seminar Pertumbuhan Gereja. Jakarta: Panitia SPG, 1989

Subagio, Andreas Bambang, Pengantar Riset Kualitatif \& Kuantitatif. Bandung: Kalam Hidup, 2004

Sudibyo, Irwanto. "Pelayanan Kepemimpinan Penggembalaan Menurut Kisah Para Rasul 20:17-38." Jurnal Teologi Gracia Deo 2, no. 1 (2019): 46-61.

Sukardi, Y M Imanuel. “Gereja Ekstra Biblikal Dan Tanggung Jawab Dalam Menyelesaikan Amanat Agung." KHARISMATA: Jurnal Teologi Pantekosta 1, no. 2 (2019): 37-39. http://www.ejournal.stajember.ac.id/index.php/kharismata/article/view/22.

Widjaja, Fransiskus Irwan, Daniel Ginting, and Sabar Manahan Hutagalung. "Teologi Misi Sebagai Teologi Amanat Agung." THRONOS: Jurnal Teologi Kristen 1, no. 1 (2019): 17-24.

Wiryadinata, Halim. "Mission And Evangelism : African Context." KURIOS (Jurnal Teologi dan Pendidikan Agama Kristen) 3, no. 1 (2015): 1-11. http://www.sttpb.ac.id/e-journal/index.php/kurios.

Yewangoe, Andreas A.., Tidak Ada Penumpang Gelap. Jakarta: BPK Gunung Mulia, 2009

Zaluchu, Sonny Eli. "Eksegesis Kisah Para Rasul 2:42-47 Untuk Merumuskan Ciri Kehidupan Rohani Jemaat Mula-Mula Di Yerusalem." EPIGRAPHE: Jurnal Teologi dan Pelayanan Kristiani 2, no. 2 (2018): 72-82. Accessed April 1, 2020. http://www.stttorsina.ac.id/jurnal/index.php/epigraphe.

Zebua, Arniman, "Iman Yang Bertumbuh Melalui Keteladanan Hamba Tuhan", IMMANUEL: Jurnal Teologi dan Pendidikan Kristen 1, No.1, (2020): 43-51, http://stt-su.ac.id/e-journal/index.php/immanuel/article/view/6 